\title{
Analisis Sentimen Data Twitter Mengenai Isu RUU KPK Dengan Metode Support Vector Machine (SVM)
}

\author{
Rani Nooraeni ${ }^{1}$, Aulia Fikri Fadhilah $\mathbf{I}^{2}$, Heny Dwi $\mathbf{S}^{3}$, Siti Fatimatul $\mathbf{M}^{4}$, Suciarti Pertiwi ${ }^{5}$, YulianuS \\ Ronaldias ${ }^{6}$, \\ ${ }^{1}$ Politeknik Statistika STIS \\ e-mail: ${ }^{1}$ raninoor@stis.ac.id \\ ${ }^{2}$ Politeknik Statistika STIS \\ e-mail: ${ }^{2}$ a.f.fadhilah.iskandar@gmail.com
}

\begin{abstract}
Abstrak - Komisi Pemberantasan Korupsi (KPK) merupakan lembaga independen di Indonesia yang dibentuk pada tahun 2002 untuk mengatasi masalah korupsi di Indonesia. KPK bertanggungjawab kepada publik dan menyampaikan laporannya secara terbuka dan berkala kepada presiden, DPR, dan BPK. Skor CPI Indonesia dari tahun 2015-2018 masih cenderung stagnan yakni berturut-turut 36, 37, 37 dan 38. Sidang Paripurna DPR menyepakati dilakukannya revisi UU KPK menjadi RUU Inisiatif DPR. Polemik yang terjadi sebagai akibat dari ketidakterbukaan DPR atas keputusannya untuk melakukan revisi UU KPK menimbulkan berbagai respon dari masyarakat. Salah satu media yang dapat digunakan untuk melihat respons masyarakat terkait isu ini adalah twitter. Untuk menganalisis respon masyarakat dengan menggunakan data Twitter, dapat dilakukan dengan analisis sentiment menggunakan metode pengklasifikasian Support Vector Machine (SVM). Dari model pengklasifikasian data original, training ataupun testing diperoleh hasil persentase respon berupa sentiment negatif terkait ISU RUU KPK adalah 60,9 persen lebih besar dibandingkan persentase sentiment positif sebesar 39,1 persen. Performa model SVM dalam mengklasifikasikan sentimen cukup baik karena memiliki nilai akurasi, sensitivitas dan spesivisitas masing-masing sebesar 81,32 persen, 71,47 persen dan 87,64 persen.
\end{abstract}

Keywords: RUU KPK, Twitter, Analisis Sentimen, SVM, Radial Basic Function

\section{PENDAHULUAN}

Komisi Pemberantasan Korupsi (KPK) merupakan lembaga independen yang dibentuk pada tahun 2002. Dasar hukum pendirian lembaga ini adalah Undang-Undang Nomor 30 Tahun 2002 tentang Komisi Pemberantasan Tindak Pidana Korupsi. Dalam menjalankan tugasnya, KPK bertanggungjawab kepada publik dan menyampaikan laporannya secara terbuka dan berkala kepada presiden, DPR, dan BPK.

Secara umum, penindakan Tindak Pidana Korupsi (TPK) yang ditangani KPK berdasarkan profesi/jabatan, instansi, dan jenis perkara mengalami peningkatan dari tahun ke tahun. Renstra KPK 2015-2019 menyebutkan bahwa rilis terakhir yang dipublikasikan oleh Transparansi Internasional Indonesia menunjukkan bahwa Indeks Persepsi Korupsi Indonesia mengalami kenaikan dari tahun ke tahun yaitu 36, 37, 37 dan 38. Angka 100 pada indeks ini menunjukkan keadaan bersih dari korupsi. Sementara itu, berdasarkan data Indonesia Corruption Watch (ICW) tahun 2018 kasus korupsi yang ditangani oleh KPK sebagian besar adalah kasus korupsi kelas "kakap" dimana latar belakang tersangka yang ditetapkan KPK kebanyakan sebagai Ketua atau Anggota DPRD sebanyak 103 orang dari total 198 orang/kasus yang ditangani KPK. Artinya, KPK mampu membongkar kasus dari oknum-oknum pejabat tinggi yang tidak tersentuh oleh penegak hukum lainnya.

Terlepas dari jatuh bangunnya KPK dalam menangani kasus korupsi, sidang Paripurna DPR (Kamis, 5 September 2019) menyepakati dilakukannya revisi UU KPK menjadi RUU Inisiatif DPR. Dalam revisi tersebut, terdapat 9 persoalan di draf RUU KPK. Persoalan tersebut antara lain, independensi KPK, aturan penyadapan, pembentukan Dewan Pengawas yang dipilih oleh DPR, pembatasan sumber penyelidik dan penyidik, penuntutan perkara korupsi harus koordinasi dengan Kejaksaan Agung, perkara yang mendapat perhatian masyarakat tidak lagi menjadi kriteria, pemangkasan kewenangan pengambilalihan perkara di tahap penuntutan, penghilangan kewenangan-kewenangan strategis pada proses penuntutan, dan pemangkasan kewenangan KPK untuk mengelola pelaporan dan pemeriksaan LHKPN. Tak hanya RUU KPK, pembahasan RUU KUHP oleh DPR dapat mencabut sifat khusus dari Tindak Pidana Korupsi.

Keputusan DPR untuk merevisi Undang-Undang KPK menimbulkan berbagai respon dari masyarakat. Sebagian respon masyarakat menyetujui atau 
mendukung hasil keputusan revisi tersebut, dan sebagian lainnya tidak setuju. Tanggapan/respon masyarakat terhadap revisi Undang-Undang KPK tersebut terlihat dalam cuitan mereka di berbagai media sosial termasuk twitter.

Berdasarkan latar belakang tersebut, maka penelitian ini ingin melihat bagaimana respon masyarakat terhadap rencana DPR untuk merevisi UU KPK dengan menggunakan data dari twitter. Untuk menjawab permasalahan tersebut akan dilakukan analisis sentimen yang merupakan proses pengklasifikasian text ke dalam sentimen positif dan negatif menggunakan metode Support Vector Machine (SVM). Sehingga tujuan penelitian ini adalah untuk mengklasifikasikan respon masyarakat terkait ISU RUU KPK menggunakan SVM.

\section{Analisis Sentimen}

Analisis sentimen (sentiment analysis) atau dikenal sebagai opinion mining adalah suatu proses secara otomatis dalam memahami, mengekstrak dan mengolah data tekstual untuk mendapatkan informasi (Lee \& Pang, 2008). Menurut Liu (2012), analisis sentimen merupakan bidang ilmu yang menganalisis pendapat, sikap, evaluasi, dan penilaian terhadap suatu peristiwa, topik, organisasi, maupun perseorangan.

\section{Text Mining}

Text mining atau text analytics adalah suatu istilah yang menggambarkan sebuah teknologi yang mampu menganalisis data teks semi-terstruktur dan tidak terstruktur (Jamil: 2017, dalam Praptiwi: 2018). Text mining berguna untuk memahami konten emosional kata-kata secara terprogram.

\section{Support Vector Machine}

Support Vector Machine (SVM) diperkenalkan oleh Vapnik pada tahun 1992 sebagai suatu metode klasifikasi yang efisien untuk masalah nonlinear. SVM bekerja dengan menemukan fungsi pemisah (hyperplane) dengan memaksimalkan jarak antarkelas (Praptiwi, 2018).

Untuk menangani kasus nonlinear, SVM dimodifikasi dengan memasukkan fungsi kernel. Beberapa fungsi kernel yang biasa digunakan pada SVM adalah sebagai berikut.

\section{Polynomial kernel}

Polynomial merupakan Kernel trick yang cocok digunakan pada pengklasifikasian dengan dataset training sudah normal. Dinyatakan dalam persamaan:

$$
K\left(\vec{x}_{i}, \vec{x}_{j}\right)=\left(\vec{x}_{i}, \vec{x}_{j}+1\right)^{d}
$$

\section{Radial Bias Function (RBF)}

RBF merupakan fungsi kernel trick yang paling umum digunakan untuk mengklasifikasi dataset yang tidak terpisah secara linear. Kernel jenis ini memiliki akurasi training dan prediction yang sangat baik. Dinyatakan dalam persamaan:

$$
K\left(\vec{x}_{i}, \vec{x}_{j}\right)=\exp \left(-\left\|\vec{x}_{i}-\vec{x}_{j}\right\|^{2}\right) \gamma
$$

\section{Sigmoid kernel}

Sigmoid merupakan kernel trick pengembangan dari jaringan saraf tiruan. Dinyatakan dalam persamaan:

$$
K\left(\vec{x}_{i}, \vec{x}_{j}\right)=\tanh \left(\overrightarrow{a x}_{i}+\vec{x}_{j}+\beta\right)
$$

\section{Evaluasi Performansi Klasifikasi}

Akurasi, sensitivity dan specificity

Ukuran ketepatan klasifikasi dapat dilihat dari akurasi klasifikasi. Akurasi menunjukkan performansi teknik klasifikasi secara keseluruhan, semakin tinggi akurasi klasifikasi berarti semakin baik performansi teknik klasifikasi.

Tabel 1. Confusion Matrix Untuk Hasil Klasifikasi

Biner

\begin{tabular}{lcc}
\hline \multirow{2}{*}{ Kelas } & \multicolumn{2}{c}{ Kelas prediksi } \\
\cline { 2 - 3 } sebenarnya & Positif & Negatif \\
\hline Positif & $\mathrm{tp}$ & $\mathrm{fn}$ \\
Negatif & $\mathrm{fp}$ & $\mathrm{tn}$ \\
\hline
\end{tabular}

$\operatorname{Akurasi}$ klasifikasi $(\%)=\frac{t p+t n}{t p+f p+t n+f n}$

Sensitivity $(\%)=\frac{t p}{t p+f n}$

Specificity $(\%)=\frac{t n}{f p+t n}$

\section{Penelitian Terkait}

Penelitian dengan menggunakan metode analisis sentimen telah banyak dilakukan. Salah satunya adalah penelitian yang dilakukan oleh Patil et al. di India pada tahun 2007 untuk mengklasifikasikan opini masyarakat terhdap tokoh politik berdasarkan komen dan cuitan mereka di twitter. Terdapat dua kelas sentimen yang digunakan, yaitu sentimen positif dan sentimen negatif. Metode pengklasifikasian yang digunakan dalam penelitian tersebut adalah Support Vector Machine (SVM).

Penelitian lain dilakukan oleh Hidayatullah dan Azhari pada tahun 2014 di Indonesia untuk menganalisis sentimen masyarakat terkait tokoh tertentu menjelang pemilihan umum. Metode klasifikasi yang digunakan adalah Nä̈ve Bayes Classsifier dan Support Vector Machine. Penelitian ini menggunakan data tweet berbahasa Indonesia. Data tweet tersebut diklasifikasikan dalam kelas positif dan negatif.

\section{METODOLOGI PENELITIAN}

\section{Sumber Data}

Data yang digunakan dalam penelitian ini adalah data cuitan akun pengguna twitter pada selang waktu 4 - 25 September 2019 yang diperoleh melalui scraping dengan menggunakan software anaconda 
promt dan twitterscraper. Pemilihan rentang waktu data didasarkan dari visualisasi pada google trend. Visualisasi ini menunjukkan bahwa kata RUU KPK mulai tinggi dipencarian google pada tanggal 4 September 2019.

\section{Cakupan Masalah}

Masalah yang diangkat pada penelitian ini adalah respon pengguna twitter terkait kesepakatan DPR untuk merevisi UU No. 20 Tahun 2002 tentang Komisi Pemeberantasan Tindak Pidana Korupsi. Jumlah cuitan yang dianalisis dalam penelitian ini adalah 10.399 cuitan.

\section{Pengumpulan dan Pengolahan Data}

1. Pengumpulan Data

Data yang digunakan dalam penelitian ini didapatkan melalui twitter dengan proses scraping. Sebelum dilakukan proses pengumpulan data, terlebih dahulu menginstal software yang diperlukan untuk scraping data twitter, yaitu python prompt dan twitterscraper. Data disimpan dalam bentuk .csv yang kemudian digunakan pada tahap preprocessing. Data yang berhasil dikumpulkan dalam proses ini adalah 9.858 cuitan.

2. Pengolahan Data

a. Preprocessing data

Pada tahap ini dilakukan proses cleaning, stemming, tokenizing, dan stopwords removal

1) Text cleaning

Text cleaning bertujuan untuk menghilangkan HTML dan URL, menghapus emoji, mention dan hashtag, menghapus kata-kata slang, dan menghilangkan simbol atau huruf yang tidak relevan.

2) Stemming

Stemming bertujuan untuk mereduksi suatu kata ke bentuk dasarnya.

3) Tokenizing

Tokenizing merupakan proses untuk memecah konten tekstual menjadi katakata, istilah, simbol, atau beberapa elemen bermakna lainnya yang disebut token.

4) Stopwords removal

Tahap ini bertujuan untuk menghilangkan kata-kata yang tidak penting seperti kata: yang, di, ke, dari, tetapi, untuk, dan sebagainya.

b. Pelabelan kelas sentimen

Setelah melaui proses preprocessing, selanjutnya akan dilakukan analisis setimen untuk pelabelan data. Proses pelabelan data dilakukan dengan membandingkan kata per kata dengan kamus lexicon Bahasa Indonesia dengan menghitung skor sentimen. Pembobotan kata dilakukan dengan menghitung frekuensi kemunculan kata.
Cara menentukan kelas sentimen adalah dengan menghitung skor jumlah kata positif dikurangi dengan skor jumlah kata negatif dalam setiap kalimat. (Susanti,2016) Kalimat yang memiliki skor < 0 akan masuk ke dalam kelas negatif, kalimat dengan skor $=0$ akan masuk kelas netral dan kalimat yang memiliki skor $>0$ akan masuk kelas positif. Namun, dalam penelitian ini hanya menggunaka dua kelas pelabelan yaitu sentimen positif dan sentimen negatif.

\section{c. Wordcloud}

Wordcloud adalah salah satu hasil dari metode text mining yang menampilkan kata-kata populer terkait dengan kata kunci internet dan data teks. Menurut PBC (dikutip dalam Arkhamsiagustinah, 2015) wordcloud sering digunakan untuk menyoroti istilah populer atau trend berdasarkan frekuensi pengguna. Menurut Shawn Graham, Ian Milligan, dan Scott Weingart (dikutip dalam Arkhamsiagustinah, 2015) wordcloud merupakan pendekatan yang dapat menjelaskan pertanyaan penelitian dengan sangat cepat dan mudah, dapat menjelajahi word cloud secara singkat dan dapat melakukan analisis yang komprehensif. Kata yang paling sering muncul di dalam data teks akan memiliki bentuk yang paling besar, begitu pula sebaliknya.

\section{d. Klasifikasi dengan Support vector Machine}

Setelah dilakukan pelabelan, data dipisahkan menjadi dua jenis penggunaan, data training dan data testing. Data training yang digunakan dalam penelitian ini adalah $80 \%$ dari total data yang digunakan sedangkan data testing merupakan 20\% sisanya. Data training digunakan untuk menentukan parameterparameter yang digunakan pada proses pengklasifikasian sedangkan data testing digunakan untuk mengevaluasi hasil pengklasifikasikan.

Untuk mengukur ketepatan pengklasifikasian, dilakukan evaluasi model seperti akurasi, presisi, dan sensitivitas dengan menggunkan data testing.

\section{HASIL DAN PEMBAHASAN}

\section{Preprocessing Data}

Jumlah cuitan yang didapat pada tahap scraping data twitter adalah 9. 858 cuitan. Data ini kemudian dilakukan preprocessing yang mencakup text cleaning, stemming, tokenizing, dan pengapusan stopwords, agar diperoleh data yang siap digunakan pada tahap analisis sentimen. Setelah melewati tahap preprocessing, diperoleh $43 \%$ (4258 tweets) data yang siap digunakan pada tahap analisis sentimen. 


\section{Pelabelan kelas Sentimen}

Setelah melewati tahap preprocessing data, selanjutnya dilakukan pelabelan yang terdiri dari kelas sentimen positif dan kelas sentimen negatif.

Tabel 2. Contoh Hasil Pelabelan Kelas Sentimen

\begin{tabular}{|c|c|c|}
\hline Tweets & Skor & $\begin{array}{l}\text { Kelas } \\
\text { Sentimen }\end{array}$ \\
\hline (1) & (2) & (3) \\
\hline $\begin{array}{l}\text { sejarah aksi demo pro } \\
\text { pemerintah ricuh negara } \\
\text { revolusi sosial aksi antipki } \\
\text { aksi dukung }\end{array}$ & 6 & Positif \\
\hline $\begin{array}{l}\text { mahasiswa legenda viral } \\
\text { foto undang narasumber pro } \\
\text { seluruh masyarakat aspirasi }\end{array}$ & 3 & Positif \\
\hline $\begin{array}{l}\text { orang papua demo isu } \\
\text { rasisme orang sumatra } \\
\text { kalimantan isu kabut asap } \\
\text { orang jabodetabek kota } \\
\text { besar isu pusing tinggal } \\
\text { tunggu momen }\end{array}$ & -15 & Negatif \\
\hline $\begin{array}{l}\text { dua mata koin fungsi cara } \\
\text { garis besar tindak cegah } \\
\text { korupsi mepreteli fungsi } \\
\text { tindak mulai gawai } \\
\text { independen mekanisme } \\
\text { sedap sidik tuntut }\end{array}$ & -9 & Negatif \\
\hline
\end{tabular}

Setelah data diberi label, selanjutnya dihitung frekuensi suatu kata yang digunakan oleh pengguna twitter. Data yang digunakan dalam penelitian ini adalah data twitter pada selang waktu 4 - 25 September 2019 yang diperoleh melalui scraping dengan menggunakan software anaconda promt dan twitterscraper. Tabel 2 menunjukkan beberapa kata dengan frekuensi paling tinggi yang digunakan pengguna twitter berdasarkan kelas sentiment positif atau negatif

Tabel 3. Daftar Kata-kata Sentimen Positif dan Negatif berdasarkan Frekuensi Kemunculan paling Banyak

\begin{tabular}{|c|c|c|c|}
\hline \multicolumn{2}{|c|}{ Sentimen Positif } & \multicolumn{2}{c|}{ Sentimen Negatif } \\
\hline Kata & Jumlah & Kata & Jumlah \\
\hline$(1)$ & $(2)$ & $(3)$ & $(4)$ \\
\hline revisi & 376 & tolak & 495 \\
\hline dukung & 256 & dukung & 376 \\
\hline dpr & 219 & lemah & 361 \\
\hline jokowi & 137 & korupsi & 320 \\
\hline presiden & 124 & bahas & 299 \\
\hline bahas & 104 & sahkan & 284 \\
\hline
\end{tabular}

Dari tabel 2, kata yang paling sering digunakan oleh pengguna twitter pada kelas sentimen positif adalah kata "revisi" dengan frekuensi sebanyak 376 kata. Setelah itu, secara berturut-turut disusul oleh kata "dukung", "dpr", “jokowi", "presiden", dan "bahas". Sementara itu, pada kelas sentiment negatif, kata yang paling sering digunakan adalah "tolak" sebanyak 495 kata. Kemudian secara berturut-turut disusul oleh kata "dukung", "lemah", "korupsi", "bahas" dan "sahkan".

\section{Visualisasi Hasil Klasifikasi}

1. Barplot Sentimen Negatif

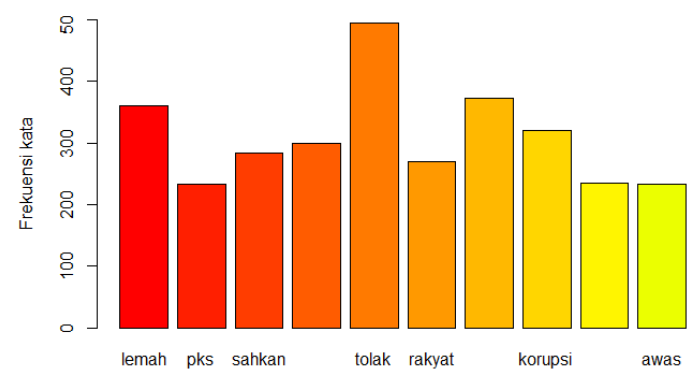

Gambar 1. Distribusi frekuensi kata-kata yang paling sering muncul pada kelompok sentiment negatif

Kata yang paling banyak muncul dari kelas negatif pada keyword RUU KPK adalah kata "tolak" dengan frekuensi sebanyak 495 kata. Hal ini menunjukkan bahwa kata "tolak", merupakan kata yang paling sering digunkan oleh pengguna twitter untuk menolak keputusan DPR dalam merevisi UU KPK.

\section{Wordcloud Sentimen Negatif}

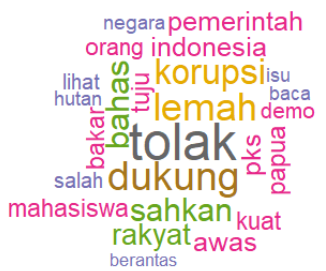

Gambar 2. Wordcloud kata-kata kelompok sentimen negatif

Ukuran kata yang tertera dalam wordcloud berbanding lurus dengan besarnya frekuensi kata tersebut muncul dalam cuitan pengguna twitter.

Semakian besar ukuran kata, semakin tinggi frekuensi kata tersebut digunakan oleh pengguna. Dari wordcloud pada gambar 2, terlihat bahwa kata "tolak" adalah kata yang paling sering muncul, diikuti dengan kata "dukung" lalu selanjutnya oleh kata "lemah" dan "korupsi". Sedangkan kata-kata lain disekitarnya berukuran lebih kecil dan relatif sama yang berarti bahwa penggunaan kata-kata tersebut tak sebanyak kata "tolak" dalam menolak 
keputusan DPR untuk merevisi UU KPK.

\section{Barplot Sentimen Positif}

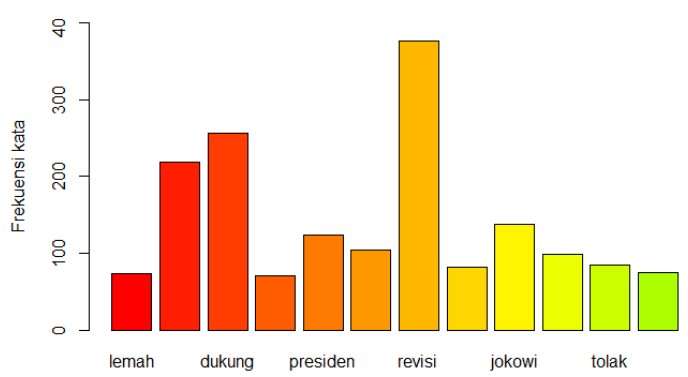

Gambar 3. Distribusi frekuensi kata-kata yang paling sering muncul pada kelompok sentiment positif

Kata yang paling banyak muncul dari kelas positif pada keyword RUU KPK adalah kata "dukung" dengan frekuensi sebanyak 256 kata. Kata inilah yang paling sering diulas oleh pengguna twitter dalam menyampaiakan pendapatnya untuk mendukung DPR dalam dalam merevisi UU KPK.

\section{Wordcloud Sentimen Positif}

Kata-kata pada wordcloud di gambar 4. merupakan bentuk pernyataan setuju pengguna twitter terhadap keputusan DPR untuk merevisi UU KPK. Kata "dukung" adalah kata yang paling sering muncul, diikuti dengan kata "dpr" lalu selanjutnya oleh kata "jokowi" dan "presiden". Kata-kata lain di sekitarnya yang berukuran lebih kecil dan relatif sama menunjukkan bahwa frekuensi kata-kata tersebut digunakan dalam menyatakan sikap setuju terhadap keputusan DPR tidak sebanyak kata "dukung”, "dpr”, dan “jokowi”.

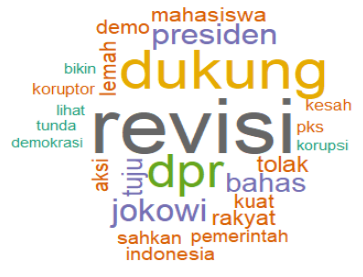

Gambar 4. Wordcloud kata-kata kelompok sentimen positif

\section{Analisis Sentimen}

Dari gambar 5., diperoleh bahwa 2.590 tweets negatif dengan persentase $60,83 \%$, dan sisanya 1.668 tweets positif dengan persentase $39,17 \%$ tweet negatif merupakan kata-kata tertentu yang digunakan oleh pengguna twitter untuk menunjukkan keberpihakan terhadap KPK. Artinya, kata-kata tersebut mewakili pengguna twitter dalam menunjukkan sikap kepercayaan mereka terhadap kinerja KPK. Karena mereka masih percaya terhadap KPK, maka revisi UU KPK sebenarnya tidak diperlukan.

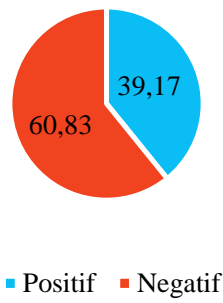

Gambar 5. Distribusi persentase cuitan berdasarkan kelas cuitan positif dan negatif

Sementara itu, tweet positif merupakan kata-kata tertentu digunakan oleh pengguna twitter dalam menunjukkan hal yang sebaliknya, yaitu pernyataan setuju terhadap keputusan DPR untuk merevisi UU KPK. Sikap setuju terhadap revisi UU KPK menunjukkan kepercayaan yang buruk terhadap kinerja KPK, sehingga dasar hukumnya yaitu UU No. 20 Tahun 2002 perlu direvisi.

\section{Klasifikasi Sentimen dengan Support Vector Machine (SVM)}

1. Pembentukan data Testing dan Training

Pada penelitian ini, sebanyak $80 \%$ dari total tweets digunakan sebagai data training, sedangkan sisanya $20 \%$ digunkan sebagai data testing. Berikut ini merupakan persentase sentimen positif dan negatif pada data awal (original), data training, dan data testing.

Tabel 4. Distribusi Persentase Cuitan berdasarkan kelas positif dan negatif pada beberapa dataset

\begin{tabular}{|l|l|l|l|}
\hline & Original & $\begin{array}{l}\text { Training } \\
\text { set }\end{array}$ & Test Set \\
\hline Negatif & 60.8 & 60.8 & 60.9 \\
\hline Positif & 39.2 & 39.2 & 39.1 \\
\hline
\end{tabular}

2. Evaluasi Model Klasifikasi SVM

Evaluasi model klasifikasi SVM dapat dilakukan dengan menghitung tingkat akurasi, sensitivitas, dan spesifisitas. Berikut ini merupakan tabel confusion matrix yang dihaslkan dari aplikasi model pada data testing.

Tabel 4. Matriks Confussion Hasil model SVM

\begin{tabular}{|c|c|c|}
\hline \multirow[t]{2}{*}{ Actual } & \multicolumn{2}{|c|}{ Predicted } \\
\hline & Positif & Negatif \\
\hline Positif & 454 & 64 \\
\hline Negatif & 95 & 238 \\
\hline
\end{tabular}

Dari hasil evaluasi, diperoleh tingkat akurasi klasifikasi dengan metode SVM Radial Bias Funtion (RBF), diperoleh akurasi sebesar 81,32\%, sensitivitas sebesar 71,47\%, dan spesifisitas $87,64 \%$. Berdasarkan ketiga ukuran tersebut menunjukkan model pengklasifikasian untuk isu RUU KPK dengan SVM sudah baik. 


\section{KESIMPULAN}

Dari hasil pengklasifikasian dengan SVM, terdapat 60,9 persen merupakan sentiment negatif menunjukkan sikap tidak setuju terhadap revisi Undang-Undang KPK. Sementara sisanya, 39,1 persen merupakan sentimen positif menunjukkan sikap setuju terhadap revisi Undang-Undang KPK. Hal ini menunjukkan bahwa berdasarkan respon dalam twitter, sebagian besar masyarakat tidak mendukung diberlakukannya revisi Undang-Undang KPK oleh DPR. Model SVM dapat melakukan pengklasifikasian respon publik tentang isu RUU KPK dengan baik mengacu pada hasil evaluasi yang cukup besar yaitu, nilai akurasi sebesar $81,32 \%$, nilai sensitivitas sebesar $71,47 \%$ dan nilai spesifisitas sebesar $87,64 \%$. Dengan demikian, respon publik dari media social seperti twitter dapat menjadi sumber informasi dan sumber data alternatif mengenai suatu isu terkini yang dapat diolah dengan berbagai metode supervised learning seperti SVM. Penelitian berikutnya bisa menggunakan sumber data dari internet dan menggunakan metode supervised learning lainnya seperti Neural Network untuk menganalisa berbagai hal yang dihasilkan dari data internet yang pada akhirnya memberikan suatu pengetahuan baru.

\section{REFERENSI}

Arkhamsiagustinah. 2015. Perbandingan Metode Second-Order Fuzzy Time Series Dari HSU dan CHEN Dalam Peramalan Produk Domestik Regional Bruto (PDRB) [skripsi]. Yogyakarta: Program Studi Statistika Fakultas Matematika dan Ilmu Pengetahuan Alam UII Yogyakarta.

Buntoro, G. A., Adji, T. B., \& Purnamasari, A. E. (2014). Sentiment Analysis Twitter dengan Kombinasi Lexicon Based dan Double Propagation. CITEE 2014 (pp. 39-43). Yogyakarta: Jurusan Teknik Elektro FT UGM.

Habibi, R., Setyohadi, D. B., \& Ernawati. (2016). Analisis Sentimen pada Twitter Mahasiswa Menggunakan Metode Backpropagation. Informatika, 103-109.

Hidayatullah, A. F., \& Azhari, SN. (2014). Analisis Sentimen dan Klasifikasi Kategori terhadap Tokoh Publik pada Twitter [seminar nasional Informatika]. Jogjakarta: UPN Veteran.

Indonesia Corruption Watch. (2018). Laporan Tren Penindakan Korupsi Tahun 2018.

Jamil, H. N. (2017). Analisis Sentimen pada Online Review Menggunakan Kombinasi Metode Lexicon Based dan Naive Bayes Classifier [skripsi]. Yogyakarta: Universitas Islam Indonesia Yogyakarta.

Juditha, C. (2014). Opini Publik Terhadap Kasus "KPK Lawan Polisi" dalam Media Sosial Twitter. Jurnal Pekommas, 61-70.

Liu, B. (2012). Sentiment Analysis and Opinion Mining. Synthesus Lectures on Human Languange Technologies, 5(1), 1-167.

Pang, B., \& Lee, L. (2008). Opinion mining and sentiment analysis. Foundation and Trends, 2(1-2), 1-135

Patil, G., Galande, V., Kekan, V., \& Dange, K. (2014). Sentiment Analysis Using Support Vector Machine. International Journal of Innovative Research in Computer, 2(1), 2607-2612.

Praptiwi, D. Y. (2018). Analisis Sentimen Online Review Pengguna E-Commerce Menggunakan Support Vector Machine dan Maximum Entropy [skripsi]. Yogyakarta: Universitas Islam Indonesia Yogyakarta. Dipetik September 23, 2019

Susanti, A.R. 2016. Analisis Klasifikasi Sentimen Twitter Terhadap Kinerja Layanan Provider Telekomunikasi Menggunakan Varian Naive Bayes [tesis]. Bogor: Institut Pertanian Bogor

\section{PROFIL PENULIS}

Rani Nooraeni, M.Stat, mendapatkan gelar Sarjana Statistika Terapan (S.ST) di Politeknik Statistika STIS tahun 2006 dan langsung mengabdikan diri di Badan Pusat Statistik. Kemudian tahun 2015 memperoleh Gelar M.Stat di Univeristas Padjajaran. Dan langsung ditugaskan menjadi dosen di Politeknik Statistika STIS.

Aulia Fikri Fadhilah I, sedang menempuh pendidikan jurusan sarjana statistik terapan peminatan statistik sosial kependudukan di Politeknik Statistika STIS sejak tahun 2016 hingga saat ini.

Heny Dwi S, sedang menempuh pendidikan jurusan sarjana statistik terapan peminatan statistik sosial kependudukan di Politeknik Statistika STIS sejak tahun 2016 hingga saat ini.

Siti Fatimatul M, sedang menempuh pendidikan jurusan sarjana statistik terapan peminatan statistik sosial kependudukan di Politeknik Statistika STIS sejak tahun 2016 hingga saat ini.

Suciarti Pertiwi, sedang menempuh pendidikan jurusan sarjana statistik terapan peminatan statistik sosial kependudukan di Politeknik Statistika STIS sejak tahun 2016 hingga saat ini.

Yulianus Ronaldias, sedang menempuh pendidikan jurusan sarjana statistik terapan peminatan statistik sosial kependudukan di Politeknik Statistika STIS sejak tahun 2016 hingga saat ini. 